Nataliya SIRUK, orcid.org/0000-0003-3504-9368 Candidate of Historical Sciences, Associate Professor at the Department of Scientific Discipline of Documentation and Information Technologies Academy of Recreational Technologies and Law (Lutsk,Ukraine) siruk.nat@meta.ua

\section{CONCEPTUAL ISSUES OF THE GENESIS OF UKRAINIAN BOOK PRINTING}

In this article theoretical and literary researches of historical roots of publishing on the Ukrainian grounds are generalized. The problem of existence of book-printing on Ukrainian lands before Ivan Fedorovych's coming is investigated. In the paper the complex analysis the main concepts (Russian/Soviet, Western and Ukrainian) of Ukrainian typography origin and development in the middle 15th - 16th centuries are given. Arguments of early Ukrainian bookprinting's researchers and their actuality for modern Ukrainian science are researched. The printing process in the period before I. Fedorov is investigated, the significance of the emergence of Cyrillic printing outside the Ukrainian ethnic lands are established. The analysis of the earlier unknown and prohibited archival documents can be considered such facts scientifically proven: the printing came to Ukrainian lands not from the East (from Russians), but from the West (from Germans). Ukrainian researchers proved that there was a Ukrainian printing house in Lviv until 1460. This marks the official date of Ukrainian printing 114 years earlier than the official date - the time of the publication of "Apostle» by Ivan Fedorovych in Lviv in 1574. According to archival sources the first Ukrainian printer's name is Stepan Dropan. Ivan Fedorovych should be considered the founder of permanent printing on Ukrainian lands. It is advisable to impartially reflect on the life and creative path of such prominent enlightener as Ivan Fedorovych, in establishing him as a European-level publisher and his personal contribution in the development of the national culture and printing process on Ukrainian lands. The results of the research show that the problems for our country in this area are also caused by Russia's hybrid war against Ukraine. Refutation of the hybrid narratives of the mass consciousness on the Ukrainian cultural and printing heritage is of special importance for our country in terms of confrontation in the Russian informational aggression at the present stage.

Key words: printing process, typography, Ivan Fedorovych, Ukrainian lands, Stepan Dropan, before Fedorovych printing in Ukraine.

Постановка проблеми. Питання походження українського друкованого слова в умовах сьогодення набуває особливого значення. Відновлення незалежності України у 1991 р. та відстоювання і захист державності та територіальної цілісності від російської гібридної агресії із 2014 р. цілком виправдано ставить на порядок денний необхідність об' єктивного вивчення «білих плям» в українській історії та незаангажованого радянською/ російською пропагандою трактування вже відомих фактів щодо існування раннього друкарства на українських теренах.

Генеза книгодрукування у європейських країнах та у нашій державі є недостатньо вивченою й час від часу з'являються нові факти про національних першодрукарів. Водночас узагальнюючих досліджень у цьому напрямку, які грунтувалися б на нових архівних джерелах, у вітчизняній науці немає. Актуалізує вивчення цієї проблематики існування різноманітних та навіть суперечливих концепцій походження українського друкованого слова, які тісно переплелися 3 радянською спадщиною та політичними проблемами незалежної Української держави. Міфологеми щодо зародження українського друку, які сьогодні толеруються російською та частково українською політичною елітою, продовжують руйнувати й основи гуманітарної політики України й нівелювати здобутки українського народу. Окрім того, наявна низка інших проблем політичного, економічного та культурного характеру (гібридна війна РФ проти України; відсутність комплексних, своєчасних та послідовних програм декомунізації та дерусифікації українського інформаційного поля; промоції української книги та видатних авторів і друкарів тощо), які негативно впливають на поступ друкарської галузі загалом та вивчення цієї проблематики зокрема. Тому дослідження витоків українського друкування $є$ актуальним для України й викликає зацікавлення з боку державних діячів, науковців та громадськості.

Аналіз останніх досліджень. Проблема витоків українського книгодрукування досліджувалася вітчизняними науковцями I. Огієнком, О. Мацюком, Я. Запаском, Я. Ісаєвичем, М. Тимошиком, О. Каракоз та іншими. Фахівці узагальнили внесок I. Федоровича у книговидавничу справу, виявили та проаналізували документи, які по-новому розкривають генезу друкарства на українських землях у дофедорівський період (зокрема, друкарні С. Дропана), започаткували наукові дискусії щодо періоду зародження книгодрукування та постатей перших українських друкарів. 
Метою роботи $є$ розкриття сутності та особливостей основних концепцій виникнення книгодрукування на українських землях.

Виклад основного матеріалу дослідження. Виникнення та подальший розвиток друкарства на українських теренах відрізнявся від аналогічних процесів у європейських країнах. Відносно пізніший вихід на історичну арену українського друкованого слова та вузький ринок друкованої продукції загалом були зумовлені політичними, соціально-економічними, релігійними особливостями поступу українських земель (Макарова, 2008: 9). Нестача документальних підтверджень щодо початків українського друкарства, а також вище перелічені аспекти зумовили виникнення різноманітних концепцій появи друкарства та першодрукарів на українських теренах.

Фундаментальним твердженням російської/ радянської концепції є започаткування друкарства в Україні I. Федоровим (Федоровичем). Будучи першодрукарем на російських землях (1564р.), він прибув у Львів, започаткував у цьому місті друкарню та видав у 1574 р. першу свою книгу «Апостол». Саме цей рік, згідно з російською концепцією, і є датою заснування книгодрукування в Україні (Тимошик, 2007).

Прихильники цієї теорії стверджують, що на українські терени друкування було «принесено» «просвітником» I. Федоровим 3 російських земель. Ця концепція була складовою радянської міфологеми про єдність «братніх» слов'янських народів - російського, білоруського та українського. До того ж останні два й дотепер упереджено вважаються «молодшими», які переймали досвід «старшого брата», в тому числі й в книгодрукуванні. Радянська, а згодом і російська ідеологія відкидала документально підтверджені факти, які їй суперечили, й до сьогодні продовжує існувати. Основним доказом, на думку прихильників цієї концепції, є відсутність чітко датованих стародруків, які засвідчили б про існування дофедорівського друкування на українських землях. Проте і це твердження сьогодні спростовується фахівцями, які оперують низкою документально підтверджених фактів існування ранніх друків, які можна датувати за допомогою непрямих методів визначення місця, часу виходу видання у світ, авторства і так далі. (Тимошик, 2019: 26). Російська концепція походження українського книгодрукування продовжує популяризуватися попри спростування достовірними фактами й на сучасному етапі $\epsilon$ компонентом агресивної інформаційної політики РФ стосовно України.
Західна конщепиія (С. Бандтке, Д. Зубрицький та інші) цілком відрізняється від російської. Так, іiі прихильники вважають, що друкарство в Україні поширилося із Заходу, а не з російських земель; відповідно й І. Федоров прибув на українські землі, де вже існувало книгодрукування (Тимошик, 2007). Серед аргументів цієї теорії іiі розробники використали написи на надгробку I. Федорова та працю друкаря «Апостол». Так, у перекладі надгробний напис засвідчив, що «Іван Федорович, друкар Москвитин, котрий своїм заходом занедбане друкарство обновив, умер у Львові...». Експерти стверджують оригінальність цього джерела, а також той факт, що «обновити» можна лише те, що вже існувало до приходу I. Федоровича (Босак, 2011: 5-6). Дослідники звернули увагу і на текст «Апостола», виданого I. Федоровичем, зокрема: «когда вселшумися въ преименитомъ граді Лвові, яко по стопамъ ходяще топтанымъ нікоєго богоизбранна мужа начахъ глаголати в себі молитву сію» (Тимошик, 2007). Даний текст засвідчує про згадку самим I. Федоровичем тих, хто йому передував у сфері друкування книг. Непрямими аргументами на користь цієї концепції дослідники вважають імовірність існування львівської друкарні до приходу сюди I. Федоровича у 1574 p. (у Львові були для цього наявні соціально-економічні та культурні передумови (Босак, 2011: 3).

У зв'язку з вище зазначеним постає необхідність об'єктивного висвітлення діяльності I. Федоровича як друкаря, його внеску у поступ російського та українського друкованого слова. На сучасному етапі вже достеменно відомо, що він не був першопрохідцем у друкарській справі ні на українських, ні навіть російських землях. Адже фахівці довели про існування анонімної друкарні у Московській державі у 1553 р., тобто до початку діяльності І. Федоровича (Андрійчук, 2005: 148). Попри вагомий вклад у книговидавничу справу, I. Федоровича слід вважати фундатором постійної друкарської справи на українських теренах (Ісаєвич, 2002: 106).

Грунтовний аналіз цієї проблематики здійснили саме украӥнські вчені. Одним із перших російську концепцію витоків українського книгодрукування піддав сумніву I. Крип'якевич («Іван Федорович - перший український друкар» (1918 р.). На думку науковця, I. Федорович прибув на українські землі, коли тут вже існувало друкарство (Литвин, 2011: 532). Першим грунтовним узагальнюючим дослідженням цієї проблематики стала праця I. Огієнка «Історія українського друкарства» (1925р.). У Радянській державі ця робота була заборонена, оскільки суперечила офіційній 
ідеології й стверджувала першість виникнення українського друкарства над російським. Лише у 1994 р. іiі було введено до наукового обігу, що своєю чергою започаткувало фахові дискусії щодо генези та поступу вітчизняного книгодрукування. Відзначимо, що дослідник на основі масиву опублікованих джерел спростував міфологему про заснування друкарства на українських землях I. Федоровичем (Огієнко, 1994; Тимошик, 2007).

Проблема виникнення друкарства на українських теренах має тісний зв'язок із гіпотезою про появу українського книгодрукування за межами українських етнічних земель, а також локалізації перших українських видавництв. Так, існує припущення про існування книговидавничих центрів у Львові, Києві, Острозі чи Грушеві (Андрійчук, 2005: 148). Саме I. Огієнко висловив думку, що слід розділити історію існування українського друку на етапи. Так, першою стадією можна вважати існування друкарень поза українськими етнічними землями, а другою - власне на українських теренах. Дослідник стверджував, що відлік українського друкарства слід починати 31491 p. Така дата обумовлена, на думку I. Огієнка, появою у м. Кракові замовлених українською громадою у німецького друкаря Ш. Фіоля кириличних книг «Часословецы» та «Октоїх». Підтвердженням саме українського походження стародруків були мовні, правописні характерні риси та використання для виготовлення книг рукописів Грушівського монастиря (Черниш, 2010).

Цю гіпотезу підтвердив ще один український дослідник О. Орос. Так, на думку науковця, основи видань краківського друкаря створювалися в осередку с. Грушів (тепер - Закарпатська область), які потім доопрацьовувалися у Кракові. Переконливим аргументом на користь цієї гіпотези став відкритий серед інших архівних документів рукопис-оригінал «Октоїха», який й став основою стародруку Ш. Фіоля (Орос, 1995: 51). Тобто, слов'янське (та й українське) друкування виникло задовго до створення друків Ш. Фіоля (Андрійчук, 2005: 156). Детальний аналіз інших кириличних стародруків Ш. Фіоля («Тріодь Пісна», «Тріодь Цвітна», «Псалтир»), який було здійснено О. Оросом, став основою для припущення, що ці видання додруковувалися не Ш. Фіолем через відсутність вихідних даних. Дослідник стверджував про походження цих видань 3 дофіолівського друкарського осередку, який міг розташовуватися у Грушівському монастирі (Орос, 1995: 52).

На думку Л. Волкотруб, серед слов'янських народів першими друкувати книги стали чехи (1478 p.), другими - українці. 3 точки зору дослід- ниці, друкування кирилицею введено вищезазначеними виданнями Ш. Фіоля у 1491 р. (Волкотруб, 2010: 7). Хоча сам видавець був за етнічною приналежністю не українцем, але виготовлені ним друки призначалися для користування саме українцями. На підтвердження цього можна зазначити, що краківські видання на рубежі XV-XVI ст. іменувалися "руськими книгами», які водночас $\mathrm{i}$ виготовлялися на замовлення української громади та згодом поширилися на українські етнічні території (Сірополко, 1943).

Отож, гіпотетично перший кириличний друкарський осередок за межами слов'янського світу міг розташовуватися в польському Кракові. Друкарня Ш. Фіоля сьогодні вважається першим центром друкування кириличних видань для українських та суміжних земель, причому поза межами України.

Революційною у вітчизняній науці стала наукова розвідка О. Мацюка «Чи було книгодрукування на Україні до Івана Федорова?» (1968р.). Ïї основу склала низка відкритих дослідником архівних джерел, зокрема, Центрального державного історичного архіву України у Львові. Згідно 3 виявленими документами (а саме: «Звернення монахів-василіан монастиря Св. Онуфрія у м. Львові до фіскальної колегї̈» (23 липня 1791 р.); «Пояснювальна записка провізорів ставропігійного братства» (20 жовтня 1792 р.) у Львові функціонала друкарня С. Дропана 31460 р., тобто аж за 114 років до прибуття у місто видавця I. Федоровича (Босак, 2011: 4). Оригінальність документів не викликає сумнівів i, таким чином, безсумнівними є аргументи існування львівської друкарні. Остання була у підпорядкуванні згаданого монастиря з 1460 р., коли була отримана в дарунок від власника С. Дропана. Іншими словами, у джерелах згадано й про існування друкарні у Львові до згаданої дати (1460р.), що підтверджується документально й стабільними прибутками львівського осередку. Виготовлене у цій друкарні «Писання Св. І. Золотоустого» двічі перевидавалося українським шрифтом, а зразок другого видання (1614 p.) навіть віднайдено науковцями (Тимошик, 2019:31).

Згадки та непрямі свідчення про видавничий осередок С. Дропана фахівці віднайшли й в інших архівних джерелах та наукових публікаціях. Серед них - «Хроніка Онуфріївського монастиря» 1771 р., опублікована М. Гриневицьким. У документі існує згадка про привілей монастирю Св. Онуфрія, наданий 1460 р. вже згаданим С. Дропаном, а також про його згубу (Босак, 2011: 4). Вивчений О. Мацюком інвентар книг у фондах бібліотеки Словітського монастиря (1826 р.) показав наявність у сховищі ранньодатованих украї- 
номовних друків: Новий тестамент українською мовою почаївського видання 1511 р.; Тріодіон київського видання 1527 р.; Тріодіон київського видання 1540 р.; Анфологіон львівського видання 1542 р.; Служебник львівського видання 1546 р.; Епістоляріон або Апостол львівського видання 1566 р. (Шишкіна, 2011). Отож, у цьому документі було згадано три стародруки львівського видавництва дофедорівських часів, два київських i одне почаївське. Це джерело засвідчило про наявність друкованих видань тодішньою українською мовою задовго до публікації І. Федоровичем «Апостола» у 1574 р. (Тимошик, 2019: 36).

Використання непрямих відомостей про дофедорівські публікації зумовлене відсутністю оригінальних стародруків С. Дропана у науковому обігу (з низки причин вони не дійшли до наших днів). Проте це не означає, що такі видання ніколи не існували, а зумовлено історичними передумовами, малим тиражем та іншими причинами. Так чи інакше, це питання потребує подальшого вивчення, і цілком можливо, що ще невідомі архівні документи 3 цієї проблематики потребують свого відкриття і вивчення науковцями (Босак, 2011: 7; Шишкіна, 2011).

Отож, нові архівні документи, відкриті та досліджені О. Мацюком, свідчать про існування львівського друкарського осередку з 1460 р. та фундатора українського друкованого слова - Степана Дропана. Ця концепція була підтримана i розширена іншими вітчизняними фахівцями, це: М. Марченко, Г. Сургай, П. Плющ, О. Губко, М. Савка, Я. Запаско та інші. (Андрійчук, 2005: 151). Наприклад, В. Стасенко, С. Немиров- ський та інші запропонували власні судження на підтримку цієї теорії, вказавши на наявність в українських землях, зокрема, у Львові матеріально-технічних основ для появи друкарської справи (Макарова, 2008: 9).

Висновки. Таким чином, можна констатувати існування російської, західної та української концепцій генези українського друкарства. Російська концепція стверджувала I. Федорова першодрукарем, який «приніс» 3 російських на українські землі друкарство (1574р.). Ряд вчених (Є. Бандтке та інші) вважали, що поширення друкарської справи на українських землях прийшло із Заходу й набагато раніше дати початку діяльності I. Федоровича в Україні, якого вважали виключно засновником постійного друкарства. Низка основоположних праць вітчизняних вчених заперечили твердження радянської концепції про витоки українського друкованого слова. Введення до наукового обігу низки архівних документів та їх вивчення українськими науковцями (I. Огієнко, О. Мацюк, О. Орос та інші) дозволяє стверджувати, що друкарська справа прийшла на українські землі не зі Сходу (тобто Московської держави), a iз Заходу (тобто перейнято від німців). Датою появи книгодрукування, за новими джерелами, слід вважати 1460 р., а першопрохідцем у цій сфері - Степана Дропана, який, за віднайденими документами, передав майно друкарні монастирю Св. Онуфрія у м. Львів. Постать та здобутки І. Федоровича сьогодні критично переосмислено вітчизняними науковцями. Його можна вважати не фундатором українського друкованого слова, а лише постійного друкарства на українських теренах.

\section{СПИСОК ВИКОРИСТАНИХ ДЖЕРЕЛ}

1. Андрійчук М. Т. Генеза книгодрукування на теренах України : інформаційна ситуація у вітчизняній історіографії XX ст. Технологія і техніка друкарства. 2005. № 2 (8). С. 147-157.

2. Босак О. І., Савчук Г. М. Друкарство на українських землях перед прибуттям Івана Федоровича. Поліграфія $i$ видавнича справа. 2011. № 3 (55). С. 3-10.

3. Волкотруб Л.М. До питання про історію розвитку книгодрукування. Сторінки історії. 2010. Вип. 30. С. 5-13.

4. Запаско Я., Мацюк О., Стасенко В. Початки українського друкарства. Львів : Центр Європи, 2000. 223 с.

5. Ісаєвич Я. Українське книговидання: витоки, розвиток, проблеми. Львів, 2002. 520 с.

6. Каракоз О. О. Історія книги. Київ: Вид-во Ліра-К, 2020. 360 с.

7. Литвин Т. Наукові розвідки Івана Крип'якевича про Івана Федорова. Записки Львівської наиіональної науковоі бібліотеки України імені В. Стефаника. 2011. № 3. С. 531-556.

8. Макарова М. В. Друкована книга XVI-XVIII ст. як фактор спадкоємності духовної культури України: автореф. .... канд. культурології : 26.00.01. Київ, 2008. 24 с.

9. Огієнко І. І. Історія українського друкарства. Київ : Либідь, 1994. 448 с.

10. Орос О. Започаткування слов'янського книгодрукування при Грушівському монастирі. Ужгород, 1995. 94 с.

11. Тимошик М. Перший український друкар Степан Дропан, а не Іван Федорович. Украӥнський інформаиійний nростір. 2019. № 2 (4). С. 24-62.

12. Тимошик М. Українська книжка як об'єкт фальсифікацій. Дзеркало тижня. 2007. Вип. 40. URL: https://dt.ua/ CULTURE/ukrayinska_knizhka_yak_obekt_falsifikatsiy.html

13. Сірополко С. Швайпольт Фіоль - перший друкар слов'янських кириличних книг [за ред. Свгена Юл. Пеленського]. Краків-Львів : Українське видавництво, 1943. 15 с. URL: https://diasporiana.org.ua/ukrainica/siropolkos-shvajpolt-fiol-pershyj-drukar-slov-yanskyh-kyrylivskyh-knyg/ 
14. Черниш Н. І. Українське друкарство у студіях Івана Огієнка. Всеукраїнська асоиіащія музеїв. 2010.22 листопада. URL: https://cutt.ly/Uh9KQMY.

15. Шишкіна Є. К. Дискусії навколо питання зародження книгодрукування в Україні. Переяславская рада: её историческое значение и перспективы развития восточнославянской циивилизации: сб. науч. тр.: по матер. 5-й Междунар. науч.-практ. конф., Харьков, 2011. URL: http://repository.kpi.kharkov.ua/handle/KhPI-Press/22952.

\section{REFERENCES}

1. Andriichuk M. T. Geneza knygodrukuvannia na terenach Ukrainy : informaciina sytuastia u vitchyznyanii istoriografii XX st. [Genesis of book printing on Ukrainian lands]. Technologiya i technika drukarstva. 2005. № 2 (8). Pp. 147-157 [in Ukrainian].

2. Bosak O. I., Savchuk H. M. Drukarstvo na ukrayinskyh zemlyah pered prybuttiam Ivana Fedorovycha [Before Ivan Fedorovych printing process on Ukrainian lands] Poligrafia $i$ vydavnycha sprava. 2011. № 3 (55). Pp. 3-10 [in Ukrainian].

3. Volkotub L. M. Do pytannia pro istoriyu rozvytku knygodrukuvannia [Some aspects from history of book printing development] Storinky istoriyi. 2010. Vol. 30. Pp. 5-13 [in Ukrainian].

4. Zapasko Ya., Matsyuk O., Stasenko V. Pochatky ukrainskogo drukarstva [The origins of Ukrainian book printing]. Lviv: Tsentr Yevropy, 2000. 223 p. [in Ukrainian].

5. Isayevych Ya. Ukrainske knygovydannia: vytoky, rozvytok, problem [Ukrainian book printing: origins, development, problems]. Lviv, 2002. 520 p. [in Ukrainian].

6. Karakoz O. O. Istoriya knygy [History of the book]. Kyiv: Vid-vo Lira-K, 2020. 360 p. [in Ukrainian].

7. Lytvyn T. Naukovi rozvidky Ivana Krypyakevycha pro Ivana Fedorova [Ivan Krypyakevych's scientific investigations of Ivan Fedorov]. Zapysky Lvivskoyi natsionalnoyi naukovoyi biblioteky Ukrayiny imeni V. Stefanyka. 2011 . № 3. Pp. 531-556 [in Ukrainian].

8. Makarova M. V. Drukovana knyga XVI-XVIII st. Yak factor spadkoyemnosti duhovnoyi kultury Ukrayiny [Printed book XVI-XVIII centuries as a factor of the continuity of spiritual culture of Ukraine] : avtoref. ... kand. kulturologiyi: 26.00.01. Kyiv, 2008. 24 p. [in Ukrainian].

9. Ogiyenko I. I. Istoriya ukrainskogo drukarstva [History of Ukrainian book printing]. Kyiv: Lybid, 1994. 448 p. [in Ukrainian].

10. Oros O. Zapochatkuvannya slovyanskogo knygodrukuvannya pry Grushivsomu monastyri [The origins of the Slavic book printing at the Hrushiv monastery]. Uzhgorod, 1995. 94 p. [in Ukrainian].

11. Tymoshyk M. Pershyi ukrainskyi drukar Stepan Dropan, a ne Ivan Fedorovych [The first Ukrainian printer was Stepan Dropan, not Ivan Fedorovich]. Ukrayinskyi informatsiinyi prostir. 2019. № 2 (4). Pp. 24-62 [in Ukrainian].

12. Tymoshyk M. Ukrainska knyga yak obyekt falsyfikatsii [Ukrainian book as an object of falsifications] Dzerkalo tyzhnia. 2007. Vol. 40. URL: https://dt.ua/CULTURE/ukrayinska_knizhka_yak_obekt_falsifikatsiy.html [in Ukrainian].

13. Siropolko S. Shvaipolt Fiol - pershyi drukar slovyanskih kyrylychnych knyg [Schweipolt Fiol - the first printer of Slavic Cyrillic books]. Krakiv-Lviv: Ukrayinske vydavnytstvo, 1943. 15 p. URL: https://diasporiana.org.ua/ukrainica/ siropolko-s-shvajpolt-fiol-pershyj-drukar-slov-yanskyh-kyrylivskyh-knyg/ [in Ukrainian].

14. Tchernysh N. I. Ukrainske drukarstvo u studiyah Ivana Ogiyenka [Ukrainian printing in the Ivan Ogienko's researches]. Vseukrainska asotsiatsiya muzeyiv. 2010. 22 Nov. URL: https://cutt.ly/Uh9KQMY [in Ukrainian].

15. Shyshkina Ye. K. Dyskusiyi navkolo pytannia zarodzhennya knygodrukuvannia v Ukrayini [Discussions on the origini of book printing in Ukraine]. Pereyaslavskaya rada: yeyo istoricheskoye znacheniye $i$ perspectivy rasvitiya vosochnoslavyanskoi tsivilizatsii: zb. nauch. tr. Kharkov, 2011. URL: http://repository.kpi.kharkov.ua/handle/ KhPI-Press/22952 [in Ukrainian]. 